UDC $613.6(576.651)$

DOI: 10.21668/health.risk/2020.4.11.eng

Research article

\title{
WORKING CONDITIONS AND WORK-RELATED PATHOLOGIES AT ENTERPRISES LOCATED IN CHUKOTKA AUTONOMOUS AREA
}

\author{
S.A. Syurin ${ }^{1}$, A.A. Kovshov ${ }^{1,2}$ \\ ${ }^{1}$ North-West Scientific Center for Hygiene and Public Health, 4 2-ya Sovetskaya Str., Saint Petersburg, 191036 , \\ Russian Federation \\ ${ }^{2}$ North-Western State Medical University named after I.I. Mechnikov, 41 Kirochnaya Str., Saint Petersburg, \\ 195067, Russian Federation
}

For many years, morbidity with work-related diseases has been higher in Chukotka Autonomous Area (ChAA) than on average in Russia.

Our research objects were working conditions and morbidity with work-related diseases. Our research goal was to examine reasons for work-related pathology occurrence, its structure, and prevalence in ChAA in 2008-2018. We examined data obtained via social-hygienic monitoring in 2008-2018 in Chukotka, paying close attention to a section entitled «Working conditions and work-related pathology».

We established that noise (17.4\%) and cooling microclimate (11.8\%) were the most widely spread hazardous occupational factors in ChAA. $20.1 \%$ workers were exposed to a combination of hazardous factors. $13.5 \%$ workers were employed at industrial objects that belonged to the $1^{\text {st }}$ surveillance group (the highest risks); $31.9 \%$ worked at economic entities from the $3^{\text {rd }}$ surveillance group (average risks). In 2008-2018 216 work-related diseases were first diagnosed in Chukotka, mostly among workers employed at mining enterprises (81.5\%). Sensorineural hearing loss / noise effects in the internal ear (35.2\%) and respiratory diseases (31.9\%) prevailed in their structure. $73.6 \%$ diseases were detected due to patients applying for medical aid themselves. In 2008-2015 there was a steady growth in work-related morbidity (from 1.94 to 13.5 per 10,000 workers), but there was a decrease in it in 2016-2018 (down to 5.11 per 10,000 workers) with considerable fluctuations in numbers of first diagnosed diseases. Risks of work-related pathology occurrence were higher in Chukotka in 2018 than in 2008: OR=2.37; CI 1.82-3.09; $\chi^{2}=43.8 ; p<0.001$.

To prevent work-related pathology in Chukotka, it is necessary to continue activities aimed at working conditions improvement, in particular, reducing exposure to noise and aerosols with predominantly fibrogenic effects in mining industry in the region.

Key words: social-hygienic monitoring, working conditions, work-related morbidity, Chukotka Autonomous Area (ChAA), occupational factors, noise, cooling microclimate.

According to the RF President Order issued on May 02, 2014 No. 296 (last edited on May 13, 2019) the Chukotka Autonomous Area (ChAA) that is located in the in the north-east of the country is included into the Arctic zone of the Russian Federation. The region has some specific features such as extreme climatic conditions, low population number (49.3 thousand people in 2018) and density ( 0.07 person per 1 square kilometer), and poorly developed social and economic infrastructure. Basic economic activities in
ChAA are mining (black and brown coal, gold, and silver), construction, energy production and distribution $[1,2]$. It is well known that workers employed in mining, a leading branch in ChAA, are among those occupational groups that run elevated risks of occupational pathology occurrence [3-5]. Arctic climatic conditions make an additional contribution into probability of health disorders $[6,7]$. Such disorders are caused by overall and local exposure to cold, high humidity, apparent seasonal photoperiodicity, strained ion-magnetic re-

(C) Syurin S.A., Kovshov A.A., 2020

Sergei A. Syurin - Doctor of Medical Sciences, Chief researcher (e-mail: kola.reslab@mail.ru; tel.: +7 (812) 717-97-83; ORCID: https://orcid.org/0000-0003-0275-0553).

Aleksandr A. Kovshov - Researcher; Assistance lecturer (e-mail: kovshov@s-znc.ru; tel.: +7 (812) 303-50-00; ORCID: https://orcid.org/0000-0001-9453-8431). 
gime, and other factors [8-10]. It is proven that combined exposure to these factors creates a so called «northern or arctic stress» that results in untimely decrease in adaptive resources of a body or even their depletion $[10,11]$.

In 2008-2018 ChAA was among RF regions with occupational morbidity levels being higher than on average in the country; they varied from 1.92 (2008) to 13.5 (2015) cases per 10 thousand people ${ }^{1,2}$. Arctic zones are usually poorly inhibited and labor resources there are scarce; therefore, when people cease their working activity too early due to occupational diseases while still being of employable age, it creates additional social and economic problems for regional development [12, 13]. The document entitled «The Basics of the RF State Policy in the Arctic zone for a period up to 2020 and further on ${ }^{3}$ set a task that scientists have to solve, namely, to achieve proper functioning of life support systems and occupational conditions in Arctic regions. A part of this task is to examine influence exerted on a human body by adverse environmental factors, including occupational ones. Industrial objects in ChAA are located far away from cities where medical theory and practice are most developed and it makes examining health of workers employed at hazardous productions in remote districts in the Polar zone even more vital.

Our research goal was to examine reasons, structure, and prevalence of occupational pathology in ChAA.

Data and methods. We examined data obtained via «Working conditions and occupational pathology» social and hygienic monitoring program in ChAA in 2008-2018. All the data were provided by the Federal Center for Hygiene and Epidemiology of the Federal Service for Surveillance over Consumer Rights Protection and Human Wellbeing (Moscow).
We processed research data with Microsoft Excel 2010 and Epi Info, v. 6.04; we also calculated Student's t-test for independent samplings, relative risk (RR), $95 \%$ confidence interval (CI), and test of fit $\chi^{2}$. Numeric data were given as simple mean and error of the mean $(M \pm m)$. Critical significance of a zero hypothesis was taken as 0.05 .

Results and discussion. In 2008-2018 several adverse occupational factors prevailed at workplaces at most industrial enterprises (each having a share that exceeded $7 \%$ ) and workers were exposed to them; they included elevated noise levels, cooling microclimate, aerosols with fibrogenic effects, labor hardness being higher than permissible levels, overall vibration, non-ionizing electromagnetic fields (EMF) and electromagnetic radiation (EMR). More than one fifth of workers were exposed to more than one adverse factor. Attention should be paid to drastic ( 2 times and higher) annual fluctuations in number of workers exposed to aerosols with fibrogenic effects, labor hardness, unfavorable lighting environment, and other adverse occupational factors. And there were both rises and falls in their levels without any apparent regularities (Table 1).

As compared with 2008, in 2018 there was greater risks of workers being exposed to elevated local vibrations $(\mathrm{RR}=2.15$; CI 1.82 $\left.2.54 ; \chi^{2}=83.6 ; p<0.001\right)$, labor intensity $\left(\mathrm{RR}=1.45\right.$; CI $\left.1.20-1.75 ; \chi^{2}=15.3 ; p<0.001\right)$, non-ionizing $\mathrm{EMF}$ and $\mathrm{EMR}(\mathrm{RR}=1.22$; CI $\left.1.12-1.34 ; \chi^{2}=19.4 ; p<0.001\right)$, unfavorable lighting environment $(\mathrm{RR}=3.15$; CI 2.71-3.66; $\chi^{2}=249.9 ; p<0.001$ ), and several adverse factors combined $(\mathrm{RR}=1.91 ; \mathrm{CI} \quad 1.80-2.02$; $\left.\chi^{2}=514.9 ; p<0.001\right)$. And on the contrary, in 2008 as opposed to 2018 , there was greater probability of exposure to aerosols with fibrogenic effects $\quad(\mathrm{RR}=2.33 ;$ CI 2.11-2.58;

\footnotetext{
${ }^{1}$ Occupational morbidity as per RF regions and Federal districts from 2008 to 2013. Trud-Ekspert. Available at: http://www.trudcontrol.ru/press/statistics/6457 (30.12.2019) (in Russian).

${ }^{2}$ On sanitary-epidemiologic welfare of the population in the Russian Federation in 2018: The State report. Moscow, The Federal Service for Surveillance over Consumer Rights Protection and Human-Well-being Publ., 2019, 254 p. (in Russian).

${ }^{3}$ The Basics of the RF State Policy in the Arctic zone for a period up to 2020 and further on No. 4877 dated September 18, 2008. Approved by the RF President D. Medvedev. The RF Government. Available at: http://government.ru/info/18359/ (30.12.2019) (in Russian).
} 
$\left.\chi^{2}=293.7 ; \quad p<0.001\right), \quad$ noise $\quad(\mathrm{RR}=1.19$ CI 1.12-1.26; $\left.\chi^{2}=33.7 ; p<0.001\right)$, chemical factors $\left(\mathrm{RR}=2.42\right.$; CI $2.18-2.67 ; \chi^{2}=320.7$; $p<0.001$ ), labor hardness being higher than permissible levels (RR $=1.39$; CI 1.27-1.52; $\left.\chi^{2}=52.2 ; \quad p<0.001\right), \quad$ biological factors $\left(\mathrm{RR}=1.69 ;\right.$ CI $\left.1.42-2.00 ; \chi^{2}=37.3 ; p<0.001\right)$, ionizing radiation $(\mathrm{RR}=2.37$; CI $1.45-3.88$; $\left.\chi^{2}=12.7 ; p<0.001\right)$, cooling microclimate $\left(\mathrm{RR}=1.31 ; \mathrm{CI} 1.20-1.42 ; \chi^{2}=40.1 ; p<0.001\right)$. Therefore, in 2008-2018 there was both increase and decrease in prevalence of certain adverse occupational factors on enterprises in ChAA and we can't state that working conditions have improved there.

We also performed a complex assessment of working conditions based on data obtained via surveillance over workers distributed into three groups according to sanitary-epidemiologic welfare at their workplaces. It was established that on average in 2008-2018 more than half workers in CAA were employed at industrial objects belonging to the $2^{\text {nd }}$ group (unsatisfactory conditions at workplaces), almost one third were employed at industrial objects form the $3^{\text {rd }}$ group (with extremely unsatisfactory conditions), and only $13.5 \%$ workers were employed at industrial objects from the $1^{\text {st }}$ group (satisfactory conditions).
Overall number of workers employed at objects under surveillance in ChAA decreased by more than 5 thousand people or $38.3 \%$ over the examined period of time.

During 11 years (in 2008 against 2018) there was a decrease in absolute number of workers employed at industrial objects belonging to the $1^{\text {st }}$ and $2^{\text {nd }}$ groups, but their shares among all employed workers increased $(p<0.001)$. As for the $3^{\text {rd }}$ group, there was a decrease both in absolute number of workers employed there and their share as well $(p<0.001)$. Therefore, this re-distribution of workers employed at industrial objects under surveillance belonging to three groups indicated that working conditions improved at industrial enterprises in ChAA in 2008-2018 (Table 2).

In 2008-2018 in ChAA occupational pathology was first diagnosed in 171 workers, 170 of them being males $(99.4 \%)$ and only one woman $(0.6 \%)$. Overall, 216 occupational diseases were diagnosed or 1.26 cases per one worker. Their average age was $55.3 \pm 0.5$ and their average working experience amounted to $26.9 \pm 0.6$ years. 110 people $(64.3 \%)$ lived in Anadyr district; 44 people $(25.7 \%)$, Bilibinskiy district; 10 people (5.8\%), Iul'tinskiy district (Egvekinot municipal district); and 7 people (4.1\%), Chaunskiy district (Pevek municipal district).

Table 1

Number of workers exposed to adverse occupational factors

\begin{tabular}{|c|c|c|c|c|c|c|c|}
\hline \multirow{2}{*}{ Adverse occupational factor } & \multicolumn{6}{|c|}{ Year } & \multirow{2}{*}{$\begin{array}{c}\text { Average } \\
\text { annual value }\end{array}$} \\
\hline & 2008 & 2010 & 2012 & 2014 & 2016 & 2018 & \\
\hline Noise & 2,223 & 2,427 & 1,549 & 2,257 & 1,282 & 1,666 & $1,900.7(17.4 \%)$ \\
\hline Cooling microclimate & 1,254 & 1,914 & 1,167 & 1,673 & 887 & 860 & $1,292.5(11.8 \%)$ \\
\hline Fibrogenic aerosols & 1,321 & 1,386 & 639 & 664 & 479 & 488 & $829.5(7.6 \%)$ \\
\hline Labor hardness & 1,124 & 611 & 313 & 1,503 & 582 & 723 & $809.3(7.4 \%)$ \\
\hline Overall vibration & 727 & 1,091 & 711 & 916 & 603 & 731 & $796.5(7.3 \%)$ \\
\hline Non-ionizing EMF and EMR & 835 & 281 & 661 & 874 & 959 & 953 & $760.5(7.0 \%)$ \\
\hline Chemical factors & 1,359 & 644 & 623 & 943 & 394 & 483 & $741.0(6.8 \%)$ \\
\hline Lighting environment & 218 & 346 & 347 & 1,389 & 499 & 658 & $576.2(5.3 \%)$ \\
\hline Local vibration & 198 & 227 & 201 & 604 & 209 & 399 & $306.3(2.8 \%)$ \\
\hline Labor intensity & 186 & 26 & 190 & 986 & 157 & 250 & $299.2(2.7 \%)$ \\
\hline Biological factors & 372 & 466 & 202 & 282 & 204 & 202 & $288.0(2.6 \%)$ \\
\hline Infrasound & 67 & 71 & 161 & 123 & 64 & 44 & $77.2(0.7 \%)$ \\
\hline Ionizing radiation & 57 & 27 & 18 & 68 & 39 & 22 & $38.5(0.4 \%)$ \\
\hline $\begin{array}{l}\text { Combined exposure to several } \\
\text { factors }\end{array}$ & 1,426 & 1,718 & 1,665 & 2,234 & 3,109 & 2965 & $2,197.3(20.1 \%)$ \\
\hline All factors & 11,367 & 11,235 & 8,447 & 1,4516 & 9,467 & 10,444 & $10,912.7$ \\
\hline
\end{tabular}


Table 2

Number and share (\%) of workers employed at objects from three groups with different sanitary-epidemiologic welfare

\begin{tabular}{|c|c|c|c|c|c|c|c|}
\hline \multirow{2}{*}{$\begin{array}{l}\text { Surveillance } \\
\text { group }\end{array}$} & \multicolumn{6}{|c|}{ Year } & \multirow{2}{*}{$\begin{array}{c}\text { Average } \\
\text { annual value }\end{array}$} \\
\hline & 2008 & 2010 & 2012 & 2014 & 2016 & 2018 & \\
\hline $1^{\mathrm{st}}$ & $2,348(12.0)$ & $2,145(10.7)$ & $2,401(14.8)$ & $2,081(14.1)$ & $1,728(12.1)$ & $2,048(14.5)$ & $2,125(13.5)$ \\
\hline $2^{\text {nd }}$ & $9,333(47.7)$ & $10,384(52.0)$ & $8,080(49.8)$ & $7,479(50.5)$ & $8,258(58.0)$ & $7,827(55.3)$ & $8,560(54.5)$ \\
\hline $3^{\text {rd }}$ & $7,895(40.3)$ & $7,446(37.3)$ & $5,728(35.3)$ & $5,249(35.4)$ & $4,258(29.9)$ & $4,275(30.2)$ & $5,009(31.9)$ \\
\hline Overall & $\begin{array}{l}19,576 \\
(100.0)\end{array}$ & $\begin{array}{l}17,500 \\
(100.0)\end{array}$ & $\begin{array}{l}16,209 \\
(100.0)\end{array}$ & $\begin{array}{l}14,809 \\
(100.0)\end{array}$ & $\begin{array}{l}14,244 \\
(100.0)\end{array}$ & $\begin{array}{l}14,150 \\
(100.0)\end{array}$ & $\begin{array}{l}15,694 \\
(100.0)\end{array}$ \\
\hline
\end{tabular}

Table 3

Reasons for occupational diseases occurrence at enterprises in CAA

\begin{tabular}{|l|c|}
\hline \multicolumn{1}{|c|}{ Parameter } & Occupational diseases (cases) \\
\hline Factors causing occupational diseases: & \\
\hline noise & $76(35.2 \%)$ \\
\hline aerosols with fibrogenic effects & $68(31.5 \%)$ \\
\hline local vibration & $27(12.5 \%)$ \\
\hline labor hardness & $25(11.6 \%)$ \\
\hline overall vibration & $16(7.4 \%)$ \\
\hline chemical factors & $2(0.9 \%)$ \\
\hline cooling microclimate & $2(0.9 \%)$ \\
\hline Circumstances causing occupational diseases occurrence: & \\
\hline underdeveloped technological processes & $139(64.4 \%)$ \\
\hline design defects of machinery, mechanisms, equipment, appliances, and tools & $53(24.5 \%)$ \\
\hline malfunction of machinery, mechanisms, equipment, appliances, and tools & $24(11.1 \%)$ \\
\hline
\end{tabular}

Occupational pathology occurred in workers employed in three brunches. 176 disease cases $(81.5 \%)$ were diagnosed in workers employed in mining including 106 coal miners and 70 mineral ore miners. 38 disease cases $(17.6 \%)$ were revealed in workers employed in transportation including 33 cases among air transport workers. 2 occupational diseases $(0.9 \%)$ were diagnosed in workers dealing with energy production and distribution.

7 out of 13 adverse occupational factors which workers contacted at their workplaces in ChAA were related to occupational pathology occurrence. In-plant noise and aerosols with fibrogenic effects had the greatest etiological significance. Physical factors (noise, local and overall vibration) prevailed $(55.1 \%)$ in the structure of adverse occupational factors that caused occupational diseases.

In most cases occupational pathology occurred due to technological processes being underdeveloped. A much smaller contribution was made by design defects and malfunctions in machinery, mechanisms, equipment, appliances, and tools (Table 3).

Diseases of the ear, respiratory organs, nervous and musculoskeletal system prevailed in the structure of occupational pathology diagnosed in workers employed at industrial enterprises in ChAA. Injuries, poisonings, and some other consequences of external causes were much less frequent. The most widely spread nosologies were such occupational pathologies as noise effects in the internal ear (sensorineural hearing loss), chronic bronchitis, mono- and polyneuropathy. Respiratory diseases (chronic bronchitis, pneumoconiosis) were predominantly diagnosed in coal miners. All occupational disorders were chronic diseases. Occupational pathology was much more frequently diagnosed when workers applied for medical aid themselves in case they felt sick rather than during obligatory medical examinations (Table 4). 
Table 4

Clinical features of occupational pathology

\begin{tabular}{|l|c|}
\hline \multicolumn{1}{|c|}{ Parameter } & $\begin{array}{c}\text { Occupational diseases } \\
\text { (cases) }\end{array}$ \\
\hline Nosologic groups including diseases of & $76(35.2 \%)$ \\
\hline ear and mastoid & $69(31.9 \%)$ \\
\hline respiratory organs & $28(13.0 \%)$ \\
\hline nervous system & $26(12.0 \%)$ \\
\hline musculoskeletal system and connective tissue & $16(7.4 \%)$ \\
\hline injuries, poisonings, and some other external causes & $1(0.5 \%)$ \\
\hline malignant neoplasms & \\
\hline Most widely spread diseases: & $76(35.2 \%)$ \\
\hline noise effects in the internal ear (sensorineural hearing loss) & $50(23.1 \%)$ \\
\hline chronic bronchitis & $27(12.5 \%)$ \\
\hline mono- and polyneuropathy & $19(8.8 \%)$ \\
\hline pneumoconiosis & $16(7.4 \%)$ \\
\hline vibration disease & $15(6.9 \%)$ \\
\hline radiculopathy & \\
\hline An occupational disease revealed via: & $159(73.6 \%)$ \\
\hline patients applying for a medical aid on their own initiative & $57(26.4 \%)$ \\
\hline periodical medical examination & \\
\hline
\end{tabular}

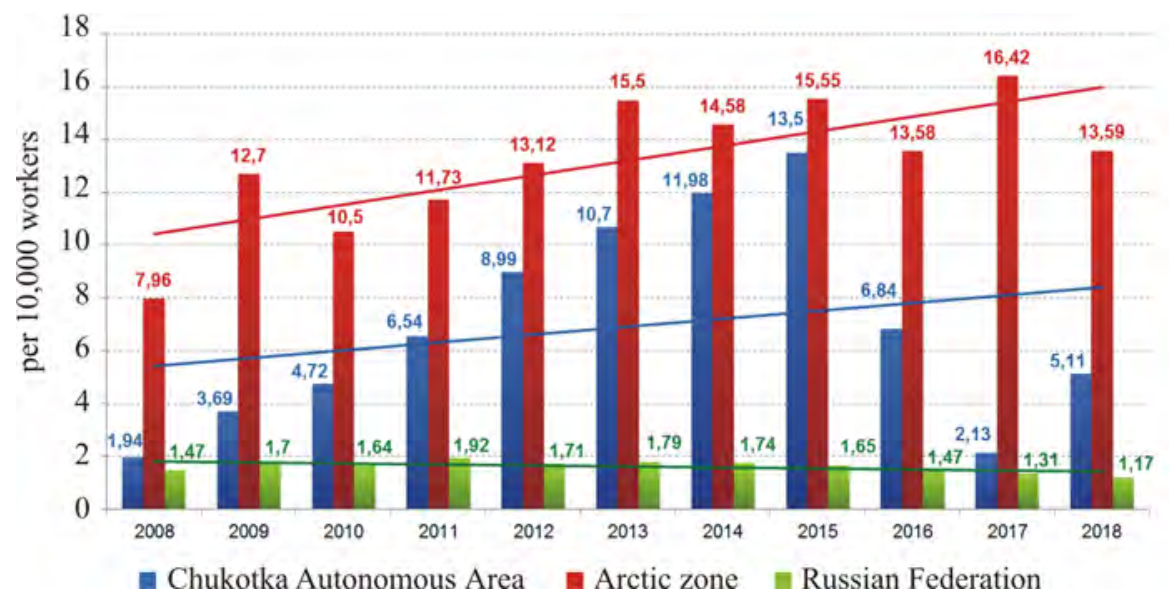

Figure. Occupational morbidity in Chukotka Autonomous Area, Arctic zone in the RF, and the country as a whole (per 10,000 workers)

Annual number of occupational diseases that were diagnosed for the first time varied within a wide range from 6 (2008 and 2017) up to 37 (2015) people. It led to significant changes in occupational morbidity levels among workers employed at industrial enterprises in ChAA. The parameter grew steadily in 2008-2015 and it went down in 2016-2018. As opposed to ChAA, in 2008-2018 overall there was an ascending trend in occupational morbidity in the Arctic zone in the Russian Federation. In Russia as a whole the parameter leveled off in 2008-2013 and then decreased in 2014-2018 (the trend was descending). In 2008-2015 dynamics of occupational morbidity in the Arctic zone as a whole and ChAA in particular was rather similar. There were significant discrepancies in 2016-2018 and it was impossible to detect any relation between drastic fluctuations in a number of first detected occupational pathology cases in ChAA and any objective factors, primarily, changes in working conditions existing at industrial enterprises in the region. Occupational pathology risk in ChAA was higher in 2018 than in 2008: $\mathrm{RR}=2.37$; CI $1.82-3.09 ; \chi^{2}=43.8 ; p<0.001$ (Figure). 
It could be assumed a priori that higher occupational morbidity in ChAA occurred, first of all, due to peculiar economic structure in the region and its natural and climatic specificity. The present work quite logically revealed that more than $80 \%$ occupational pathology cases were detected among miners. Occupational pathologies were similarly distributed as per economic activities in other Arctic regions with developed mining industry such as Murmansk region, polar zones in Krasnoyarsk region, and Komi Republic [5, 14, 15]. It is well-known that it is prohibited to employ women at mining enterprises or mines or their labor is strictly limited at such industrial objects ${ }^{4}$. Very few cases of occupational diseases among women in ChAA can be explained with mining industry prevailing in ChAA as their share is only $0.6 \%$ whereas it amounts to $14.24 \%{ }^{2}$ in Russia as a whole and is rather high in such regions as Samara region $(29.1 \%)^{5}$, Leningrad region $(43.2 \%)^{6}$, and Buryatia (21.6\%) [16].

Almost all work-related pathology cases $(98.2 \%)$ were etiologically related to five adverse occupational factors, namely, in-plant noise that was higher than permissible levels, aerosols with fibrogenic effects, labor hardness, local and overall vibration. Drastic fluctuations in adverse factors prevalence detected over the 11-year observation period were probably cue to methodical defects distorting their assessment. Only $2(0.9 \%)$ occupational pathology cases were related to cooling microclimate that was typical for extreme climatic conditions in Chukotka. Therefore, local and overall exposure to cold seems underestimated but we should remember that these adverse factors can cause reduction in physical and mental working capacity, coordination disorders, pathologies in the musculoskeletal system, and greater risks of occupa- tional injuries [17-19]. Assumed underestimated impacts exerted by cold on workers' bodies can be due to peculiarities of methodology applied to perform specific assessment of working conditions.

As for positive changes in working conditions, we should mention that in 2008-2018 there was a descending trend in exposure to two most significant adverse factors, namely elevated noise levels and aerosols with fibrogenic effects that accounted for $35.2 \%$ and $31.9 \%$ occupational pathology cases accordingly. There was also a decrease in a share of workers employed at industrial objects belonging to the $3^{\text {rd }}$ hazard group with extremely unfavorable sanitary-epidemiologic situation; and there was a simultaneous increase in number of workers employed at industrial objects form the $1^{\text {st }}$ group (satisfactory working conditions). But at the same time, in spite of all these improvements, a share of workers employed at industrial objects with extremely unfavorable working conditions $(31.9 \%)$ in ChAA was significantly higher that on average in the country where the figure was equal to $7.13 \%-9.44 \%$ in $2013-2018$. And on the contrary, a share of workers employed at industrial objects with satisfactory working conditions was 2 times lower in ChAA than on average in the country (13.5\% against $26.03-27.59 \%)^{2}$.

Another alerting fact was a significant change (up to 6 times) in annual number of first diagnosed occupational diseases and it allows assuming that performed medical examinations were not qualitative enough [20,21]. Other possible evidence here can be an unusually high number of occupational diseases that were diagnosed as a result of workers applying for medical aid themselves (73.6\%). For example, the same parameter amounted to $40.7 \%$ in Krasnoyarsk region [14] and to $12.0 \%$ in Nenets Autonomous Area [22].

\footnotetext{
${ }^{4}$ On approving the list workplaces involving hard labor and work places with adverse or hazardous working conditions that are prohibited for female workers employment: The RF Government Order issued on February 25, 2000 No. 162. Garant: information and legal databse. Available at: http://base.garant.ru/181761/\#ixzz5xKb7aV8d (11.09 2019) (in Russian).

${ }^{5}$ Occupational diseases: facts and figures. «Healthy lifestyle» information system. Available at: http://zozh.medlan. samara.ru/health/articles/detail/375498/ (09.09.2019) (in Russian).

${ }^{6}$ The ecologic report on sanitary-epidemiologic situation in Leningrad region in 2013. Occupational hygiene and workers' occupational diseases. Specialized experts division responsible for ecologic safety. Available at: https://seppeb.ru (11.09.2019) (in Russian).
} 
Conclusion. Occupational morbidity in ChAA is steadily higher than on average in the country due to poorer working conditions than in the country in general. Occupational pathology predominantly occurs in workers employed at mining enterprises; noise effects in the internal ear (sensorineural hearing loss) and respiratory diseases prevail in the structure of occupational morbidity. Occupational pathology prevention requires continuous acti- vates aimed at working conditions improvements; first of all, there should be a considerable reduction in exposure to noise and aerosols with fibrogenic effects at mining enterprises in the region.

Funding. The research was not granted any sponsor support.

Conflict of interests. The authors declare there is no any conflict of interests.

\section{References}

1. Chukotskii avtonomnyi okrug [Chukotka Autonomous Area]. Ofitsial'nyi sait polnomochnogo predstavitelya Prezidenta Rossiiskoi Federatsii v Dal'nevostochnom federal'nom okruge. Available at: http://dfo.gov.ru/district/CHU/ (14.01.2020) (in Russian).

2. Chukotskii avtonomnyi okrug: ofitsial'nyi sait [Chukotka Autonomous Area: the official website]. Available at: http://чукотка.pф (14.01.2020) (in Russian).

3. Bukhtiyarov I.V., Chebotarev A.G., Kur'erov N.N., Sokur O.V. Topical issues of improving working conditions and preserving the health of workers of mining enterprises. Meditsina truda i promyshlennaya ekologiya, 2019, vol. 59, no. 7, pp. 424-429 (in Russian).

4. Skripal' B.A. Health state and morbidity of underground mines in mining chemical enterprise in arctic area of Russian Federation. Meditsina truda i promyshlennaya ekologiya, 2016, no. 6, pp. 23-26 (in Russian).

5. Syurin S.A., Kovshov A.A. Labor conditions and risk of occupational pathology at the enterprises of the arctic zone of the Russian Federation. Ekologiya cheloveka, 2019, no. 10, pp. 15-23 (in Russian).

6. Bagnetova E.A. Features of adaptation, psychological and functional state of the human in the north. Vestnik Rossiiskogo universiteta druzhby narodov. Seriya: Ekologiya i bezopasnost' zhiznedeyatel'nosti, 2014, no. 4, pp. 63-68 (in Russian).

7. Myshinskaya Zh.M. The influence of climate and environmental factors on health in the far north. Yamal'skii vestnik, 2016, vol. 2, no. 7, pp. 79-80 (in Russian).

8. Saltykova M.M., I.P. Bobrovnitskii, M.Yu. Yakovlev, A.D. Banchenko, S.N. Nagornev. A new approach to the analysis of the influence of weather conditions on the human organism. Gigiena $i$ sanitariya, 2018, vol. 97, no. 11, pp. 1038-1042 (in Russian).

9. Solonin Yu.G., Boiko E.R. Medical and physiological aspects of vital activity in the arctic. Arktika: ekologiya i ekonomika, 2015, vol. 1, no. 17, pp. 70-75 (in Russian).

10. Khasnulin V.I., Khasnulin P.V. Modern concepts of the mechanisms forming northern stress in humans in high latitudes. Ekologiya cheloveka, 2012, no. 1, pp. 4-11 (in Russian).

11. Chashchin V.P., Dedenko I.I. Trud i zdorov'e cheloveka na Severe [Human labor and health in the Polar Regions]. Murmansk, Knizhnoe izdatel'stvo Publ., 1990, 104 p. (in Russian)

12. Govorova N.V. Human capital - a key factor of the arctic economic development. Arktika $i$ Sever, 2018, no. 31, pp. 52-61 (in Russian).

13. Fauzer V.V., Lytkina T.S., Smirnov A.V. Sustainable development of the northern regions: population dimension. Ekonomika regiona, 2018, vol. 14, no. 4, pp. 1370-1382 (in Russian).

14. Syurin S.A. occupational pathology at the enterprises of the arctic zone of Krasnoyarsk territory. Bezopasnost' i okhrana truda, 2019, no. 2, pp. 28-32 (in Russian).

15. Gorbanev S.A., Syurin S.A., Frolova N.M. Working conditions and occupational pathology of coal miners in the arctic. Meditsina truda i promyshlennaya ekologiya, 2019, vol. 59, no. 8, pp. 452-457 (in Russian).

16. Manueva R.S. Evaluation of occupational morbidity in working women of eastern Siberia. Meditsina truda i promyshlennaya ekologiya, 2017, no. 9, pp. 121-122 (in Russian). 
17. Anttonen H., Pekkarinen A., Niskanen J. Safety at work in cold environments and prevention of cold stress. Industrial Health, 2009, vol. 47, no. 3, pp. 254-261. DOI: 10.2486/indhealth.47.254

18. Kue T., Mäkinen T. The health of Arctic populations: Does cold matter? American Journal of Human Biology, 2010, vol. 22, no. 1, pp. 129-133. DOI: 10.1002/ajhb.20968

19. Cheung S.S., Lee J.K., Oksa J. Thermal stress, human performance, and physical employment standards. Applied Physiology, Nutrition, Metabolism, 2016, vol. 41, no. 6 (2), pp. 148-164. DOI: 10.1139/apnm-2015-0518

20. Babanov S.A., Budash D.S., Baikova A.G., Baraeva R.A. periodic medical examinations and occupational selection in industrial medicine. Zdorov'e naseleniya i sreda obitaniya, 2018, no. 5 (302), pp. 48-53 (in Russian).

21. Popova A.Yu. Working conditions and occupational morbidity in the Russian Federation. Meditsina truda i promyshlennaya ekologiya, 2015, no. 3, pp. 7-13 (in Russian).

22. Syurin S.A., Gorbanev S.A. Occupational pathology at the enterprises of the nenets autonomous district: risk factors, structure, prevalence. Gigiena i sanitariya, 2019, vol. 98, no. 6, pp. 652-656 (in Russian).

Syurin S.A., Kovshov A.A. Working conditions and work-related pathologies at enterprises located in Chukotka autonomous area. Health Risk Analysis, 2020, no. 4, pp. 99-106. DOI: 10.21668/health.risk/2020.4.11.eng

Received: 24.05 .2020

Accepted: 09.11.2020

Published: 30.12.2020 